\title{
HETU projekti 2001-2003
}

Olli Peltoniemi ${ }^{1)}$, Anssi Tast ${ }^{1)}$, Juha Virolainen, ${ }^{1)}$ Jonna Oravainen ${ }^{1)}$, Mari Heinonen ${ }^{1)}$

${ }^{1)}$ Helsingin yliopisto, Eläinlääketieteellinen tiedekunta, Saaren yksikkö, Pohjoinen pikatie 800, 04920 Saarentaus, olli.peltoniemi@helsinki.fi

HETU-projektin (Hedelmällisyys ja Tuotantokestävyys) keskeisenä tavoitteena oli keskittyä niihin ongelmakohtiin, jotka pääasiassa vaikuttivat emakoiden liian aikaiseen teurastukseen. Tuotannossa kestämättömyys ja keskimääräinen elinkaari, joka kestää emakolla vain 3 porsimisen verran, ovat taloudellisessa mielessä tärkeitä tuotantoa rasittavia tekijöitä. Ongelmakohtia oli tilastojen valossa lähinnä kaksi: hedelmällisyysongelmat eli kiimattomuus ja ennen kaikkea tiinehtymättömyys yhtäällä ja jalkaongelmat toisaalla. Tavoitteemme oli keskittyä näihin ongelmakohtiin käytettävissämme olevilla tutkimusmenetelmillä, sekä myös selvittää hedelmällisyyden ja jalkaongelmien yhteyttä. Käyttämämme tutkimusmenetelmät olivat epidemiologiset, lisääntymisfysiologiset ja kliiniset tutkimusmenetelmät. Tuotannon järjestelyn osalta olemme keskittyneet valaistusolosuhteisiin ja ruokintaan, kliinisellä puolella huomiota ovat saaneet etenkin jalkaongelmat, valuttelu ja parvovirusinfektio.

\section{Sikalan valaistus ja hedelmällisyys}

Nykyiset valaistussuositukset, joissa valojakson suositellaan kestävän 16 tuntia vuorokaudessa ja valotehon olevan noin 200 luxia kaikissa osastoissa, perustuvat lähinna olettamuksiin, ei niinkään tutkittuun tietoon. Osittain nykyinen suositus perustuu yksinkertaisesti siihen, että pidentämällä valojaksoa on monissa tapauksissa saatu lyhyellä aikavälillä hedelmällisyyden kannalta myönteisiä tuloksia. Tämä ilmiö on selitettävissä sillä, että valojakson kestäessä 16 tuntia on vuodenaikojen tunnistaminen lähes mahdotonta. Pitkällä aikavälillä tällainen valo-ohjelma ei ole hedelmällisyyden kannalta otollinen, sillä valaistuksessa tapahtuvat muutokset ovat osa kokonaisuutta joka vaaditaan positiiviseen valaistussignaaliin. Lisäksi sika on lyhyenpäivän lisääntyjä, joten kyseisellä suosituksella sian hormonitoiminta ei koskaan ole lisääntymisen kannalta tehokkaimmillaan. Hedelmällisyyden kannalta todennäköisesti parempi tulos saavutettaisiin, jos valojakso vaihtelisi 8 ja 16 tunnin välillä tuotantokierron vaiheesta riippuen.

\section{Valaistuksen kontrollointi}

Vaikka suomalaisissa sikaloissa valtaosa valaistuksesta tuleekin keinovalosta, pystyy emakko reagoimaan vuodenajasta johtuviin valaistusmuutoksiin ikkunoista tulevan taustavalaistuksen avulla (Tast et al. 2001). Kesällä ikkunoista tulevan lisävalaistuksen haitallisuus saattaa tuntua oudolta, mutta haitallisuus ei perustukaan itsessään lisävaloon vaan muutokseen valaistusrytmissä. Hedelmällisyyden kannalta optimaalisten valaistusohjelmien kehitteleminen sikalaolosuhteisiin on vasta hyvin alkuvaiheessa ja ainakin tässä vaiheessa valaistusohjelmien käyttö hedelmällisyyden parantamiseksi saattaa johtaa kompromissiin jonkin muun asian, kuten esim. porsaiden vieroituspainon suhteen. Tutkimuksemme ovat tuottaneet runsaasti teoriatietoa valaistusohjelmien taustaksi, mutta kenttäkokeet sikalaolosuhteissa ovat edellen kesken.

\section{Valo-ohjelmien kenttäkokeet}

Teimme vuoden 2002 aikana valo-ohjelma kokeen kahdessa noin 800 emakon porsastuotantosikalassa. Lähtötilanteessa toisessa sikalassa oli heikot ja toisessa erinomaiset hedelmällisyystulokset. Molemmissa sikaloissa oli sekä koe- että kontrolliryhmä. Koeryhmän valojakso oli porsitusosastossa ja tiineytysosastossa 8 tuntia. Joutilasosastossa, jonne eläimet siirrettiin kuukauden tiineyden jälkeen, valojakso oli 16 tuntia. Kontrolliryhmän valojakson pituus oli 16 tuntia kaikissa osastoissa. Heikon hedelmällisyyden omaava tila luopui kokeesta vajaan puolen vuoden jälkeen lopettamalla kontrolliryhmän pitämisen. Tätä kirjoittaessa on toisen sikalan tulosten analysointi vielä kesken, mutta erot ryhmien välillä näyttävät jäävän pieniksi. Tilastollisesti merkitsevä näyttäisi olevan vain ero vieroituskiimaan tulossa. Molemmissa ryhmissä korjattu porsimisprosentti (huomioi poistoeläimistä vain hedelmällisyyshäiriöiden takia poistetut) oli noin 95 ja 
kokonaisporsimisprosentti noin 90. Kontrolliryhmän emakot tulivat selkeästi nopeammin vieroituskiimaan (7,10 \pm 7,23 päivää vs. 9,79 $\pm 11,57$ päivää), mutta koeryhmän emakoiden pahnuekoko oli hieman suurempi (0,3 porsasta). Nämä tekijät kumosivat toisensa niin, että kokonaisporsasmäärässä ei ollut ryhmien välillä eroja. Kontrolliryhmässä hedelmällisyysongelmät ryvästyivät selvemmin tyypilliselle syyshedelmättömyysjaksolle.

Johtopäätösten suhteen on oltava varovainen kokeen rajallisuuden takia, mutta näyttäisi siltä, että näin yksinkertainen valo-ohjelma ei toimi toivotulla tavalla. Todennäköisimpänä selityksenä on lyhyenpäivän osuuden jääminen liian lyhyeksi ennen tiineytystä (noin 5-6 viikkoa). Lampailla tehdyt tutkimukset viittaavat, että uuden valojakson tulisi kestää noin 8 viikkoa ennen kuin hypotalamuksen ja aivolisäkkeen rakenteelliset muutokset, jotka vaaditaan hormonierityksen muuttumiseen, ehtivät tapahtua.

Olemme aloittaneet uuden kokeen, jossa lyhyenpäivän jakso kestää 8 viikkoa ennen tiineytystä. Valoohjelmaa on muutettu myös siten, että lyhyt päivä on 10 tunnin mittainen ja pitkä 16 tunnin mittainen. Lisäksi pitkä päivä alkaa heti tiineytysosastoon siirron yhteydessä. Koe on käynnistynyt kolmessa emakkorenkaassa kesäkuussa 2003, joten ensimmäisiä kokemuksia odotellaan syksyllä.

\section{Pihatto ja vapaa ruokinta}

Vuoden 2003 aikana on menossa eräässä suuressa yksikössä vapaan ruokinnan koe yhteistyössä Suomen Rehun kanssa, jossa puolet emakoista (n. $400 \mathrm{kpl}$ ) ovat vapaalla rehustuksella ja puolet on normiruokinnalla. Tarkoitus on kerätä aineistoa noin vuoden ajalta ja verrata ryhmien tuotantolukuja sekä verrata kokonaiskustannuksia. Jakson aikana suoritetaan kaksi intensiivijaksoa, joiden aikana kerätään tarkkaa tietoa emakoiden silavasta sekä painosta porsimaan mennessä ja heti vieroituksen jälkeen. Emakoiden tiineysajan ruokinnan vaikutusta porsaiden kasvuun seurataan syntymä- ja vieroituspainoja seuraamalla. Tätä kirjoitettaessa aineiston keräys on vielä meneillään, mutta esitystä pidettäessä on toivottavasti jo alustavaa analyysia tehty alkuvuoden osalta. Oletettavasti vapaan ryhmän tuotantoluvut ovat tasaisia ympäri vuoden, eli perinteistä syyshedelmättömyydestä johtuvaa notkahdusta ei olisi odotettavissa tunnusluvuissa.

\section{Ensikot ja runsas ruokinta}

Ensikkokokeessa olosuhteiden haluttiin olevan mahdollisimman lähellä nykysikaloiden olosuhteita, joten koe toteutettiin yhteistyössä Hyvinkään sikatalouden tutkimusaseman kanssa (Virolainen et al., 2003). Ensikot pidettiin kahdeksan eläimen ryhmäkarsinassa, jossa oli kippihäkit varmistamassa yksilöllisen ruokinnan. Muuten käytettiin samoja ruokintamalleja kuin vanhoilla emakoilla eli testattiin niukan ruokinnan edut heti ovulaation jälkeen yhdistettynä runsaaseen ruokintaan implantaation aikana. Lisäksi testattiin niukkaa sekä runsasta ruokintaa koko alkutiineyden ajan. Progesteroniarvot olivat jälleen matalampia runsaassa ryhmässä verrattuna muihin ryhmiin. Tästä huolimatta runsaassa ryhmässä oli paras tiinehtyvyys tarkasteltaessa viiden viikon tiineyttä, (100\% runsas, $38 \%$ mukautettu ja $25 \%$ niukka). Luteinisoivan hormonin (LH) parametreissä (keskiarvo, amplitudi, frekvenssi ja basaaliarvo) ei todettu tilastollisia eroja verrattaessa niukan ja runsaan ryhmien välisiä arvoja. Alkiokuolleisuudessa ei ollut eroja tiineinä pysyneiden välillä. Myös mukautetussa ryhmässä runsaasta ruokinnasta tuntui olevan hyötyä, sillä tarkasteltaessa tiineyttä 3-4 viikon vaiheessa ultraäänilaitteella $75 \%$ eläimistä oli tiineitä. Nähtävästi ruokinta olisi kuitenkin pitänyt aloittaa aikaisemmin ( $<10$ vrk) tai vastaavasti jatkaa pidempään ( $>17$ vrk), jotta eläimet olisivat saaneet runsaammasta ruokinnasta hyödyn. Tulokset kuitenkin vahvistivat käsitystä siitä, että ensikot hyötyvät runsaammasta ruokinnasta alkutiineydessä ainakin alhaisen hedelmällisyyden aikana loppukesällä ja syksyllä. Lisäksi ruokinnan tasojen muuntelu ensimmäisten neljän viikon aikana saattaa nostaa eläinten stressiä mikä vuorostaan vaikuttaa negatiivisesti alkutiineyteen. Hyvin todennäköistä on, että runsaampi rehustus on hyödyksi ensikoiden alkutiineydessä muunakin vuodenaikana alentaen nälästä johtuvaa stressiä. 


\section{Runsaan rehustuksen vaikutusmekanismi}

Runsaasta ruokinnasta aiheutuva alentunut progesteronitaso ääreisverenkierrossa on katsottu olevan haitallinen alkutiineyden aikana (Jindal R et al. 1996; 1997). Suorittamamme ensikkokokeen tulokset (Virolainen et al., 2003) eivät kuitenkaan vastanneet tätä käsitystä. Alentunut hormonitaso on katsottu aiheutuvan kasvaneesta metaboliasta eli kasvaneesta veren virtauksesta maksan läpi ja kiihtyneestä entsyymitoiminnasta (Prime and Symonds, 1993). Useimmiten oletetaan, että ruokinnan vaikutukset välittävä mekanismi olisi progesteroni välitteinen. Sen vuoksi halusimme selvittää onko progesteronitasoissa eroa, jos ne mitataan ääreisverenkierrosta tai vastaavasti ennen progesteronimetaboliaa maksassa, sillä on olemassa viitteitä, että progesteronilla olisi suoria vaikutuksia kohtutasolla ns countercurrent transfer mekanismillä (Krzymowski et al. 1986). Tiineet ensikot jaettiin kolmeen ruokintaryhmään ja progesteronitasot mitattiin samanaikaisesti Vena jugulariksesta sekä Vena cava caudaliksesta (Virolainen, 2003). Tulosten mukaan tasoissa oli vaihteleva ero riippuen näytteenottoajankohdasta. Progesteronitasot ennen metaboliaa saattoivat olla jopa neljä kertaa suurempia verrattuna progesteroniarvoihin Vena jugulariksessa. Suuren vaihtelevuuden vuoksi osasta ensikoista otettiin näytteitä intensiivisesti kahdenkymmenen minuutin välein kahdentoista tunnin ajan. Tällöin havaittiin progesteronin pulsaatiomainen eritys, jota ei havaita ääreisverenkierrosta. Progesteronipulssit näyttivät myötäilevän LH pulsseja, joiden tiedetään olevan keltarauhasten ylläpitämiselle olennaisessa roolissa. Ruokinnalla ei näyttänyt olevan vaikutusta progesteronitasoihin mitattuna ajankohtana (tiineysvuorokaudet 20-24). Jatkotutkimusta kuitenkin tarvitaan osoittamaan mahdolliset ruokinta tasojen vaikutukset progesteronieritykseen aikaisemmassa tiineyden vaiheessa ja sen vaikutukset alkutiineyteen. Suorittamamme tutkimus osoitti, että haluttaessa tutkia ruokinnan ja progesteronin välistä yhteyttä, ei yksittäinen verinäyte ääreisverenkierrosta ole riittävä.

\section{Emakoiden jalkaongelmat}

Arvotuilla tiloilla tutkittiin yhteensä 671 emakkoa tai ensikkoa, mikä oli keskimäärin $47 \%$ (keskihajonta $13 \%)$ tilojen kaikista emakoista ja ensikoista. Näistä 58 ontui (9\%). Tilakohtaisesti tutkittujen eläinten ontumisprosentti vaihteli 0 ja $26 \%$ :n välillä (mediaani $7 \%$ ). Yleisimmin eläimillä epäiltiin olevan pääsääntöisesti osteokondroosiperäinen ontuminen (46\% ontuvista) ja toiseksi useimmiten vaiva näytti tulevan sorkista ( $24 \%$ ontuvista). Taulukossa 1 nähdään tarkempi listaus havaituista ontumisen syistä. Ontuminen on ollut yleistä myös muissa tutkimuksissa. Esim. ruotsalaisissa emakkorenkaissa keskimäärin 9,6\% emakoista ontui (Holmgren ym., 2000). Samoilla tiloilla havaittiin myös, että emakoiden pitämisellä osaritiläpihatoissa oli yhteys lisääntyneisiin sorkkaongelmiin.

Taulukko 1: Kliininen diagnoosi tilakäynnillä havaituille ontuville emakoille ja ensikoille

\begin{tabular}{|l|c|c|}
\hline Diagnoosi & Ontuvia eläimiä, kpl & $\%$ ontuvista \\
\hline Osteokondroosi? & 27 & $46 \%$ \\
\hline Sorkkatrauma ja/tai sorkkamätä & 10 & $17 \%$ \\
\hline Pitkä ja/tai kierresorkka & 4 & $7 \%$ \\
\hline Ihovaurio & 8 & $14 \%$ \\
\hline Artriitti & 5 & $9 \%$ \\
\hline Hermostoperäinen ontuminen & 2 & $3 \%$ \\
\hline Osteokondroosi? tai artriitti & 1 & $2 \%$ \\
\hline Muu & 1 & $2 \%$ \\
\hline YHTEENSÄ & 58 & \\
\hline
\end{tabular}




\section{Parvovirus ja hedelmällisyys}

Tekemässämme tutkimuksessa 21 satunnaisesti valitussa tarkkailuun kuuluvassa pihattosikalassa 17 sikalasta löytyi vähintään 1 eläin, jolla oli HI-tiitteri infektiotasolla. Näin ollen saamme parvon insidenssiksi Suomen pihattosikaloissa $81 \%$. Näiltä 17 tilalta tutkimme eri tekijöitä, jotka voisivat vaikuttaa infektion esiintymiseen. Monimuuttuja-analyysissä p-arvoltaan merkityksellisiksi tekijöiksi tulivat: jos eläinlääkäri rokottaa aina, se antaa paremman tuloksen kuin jos tuottaja rokottaa aina itse tai sekä eläinlääkäri ja tuottaja rokottavat. Lisäksi tutkittiin pullon säilytystä avaamisen jälkeen: parhaan tuloksen saa, jos käyttää pullon kerralla ja heittää roskiin loput eikä säilytä ollenkaan. Lisäksi todettiin, että mitä korkeampi porsimakerta emakolla on, sitä korkeampi tiitteri sillä on. Sen sijaan käytetyllä rokotteella ei ollut merkitystä tiittereihin.

Toisessa tekemässämme tutkimuksessa totesimme, että vasta-aineet nousevat rokottamattomilla ensikoilla kahden rokotteen jälkeen riittävästi estämään parvovirusinfektion. Näin ollen puheet rokotteiden toimimattomuudesta voidaankin unohtaa.

\section{Emakon kohtutulehdus}

Tutkimuksessamme kävimme 21 satunnaisesti valitussa tarkkailuun kuuluvassa pihattosikalassa. Tutkimme tietyn otoksen tilan eläimistä kävelyttämällä ja samalla raottamalla häpyhuulia nähdäksemme jälkiä valuttelusta. Jos valuttelua näkyi, otimme eläimen tarkempiin tutkimuksiin. Lisäksi valitsimme valuttelijalle kontrollieläimen, joka oli porsinut yhtä monta kertaa ja oli samassa syklin vaiheessa. Jätimme tutkimuksesta pois eläimet, jotka olivat porsineet alle 5 vrk aiemmin. Valuttelu osoittautui harvinaiseksi: 9 eläintä 683 tutkitusta valutteli tilakäynnin aikana (1.3\%). Lisäksi kävimme 5 valutteluongelmatilalla, joista löysimme 10 valuttelueläintä lisää tutkimukseen.

Holmgren, N., Eliasson-Selling, L., Lundeheim, N., 2000. 16th Congress of the International Pig Veterinary Society, 17.-20.9.2000, Australia: 352 .

Jindal R, Cosgrove JR, Aherne FX, Foxcroft GR (1996) Effect of nutrition on embryonal mortality in gilts: association with progesterone. J. Anim. Sci. 74, 620-624.

Jindal R, Cosgrove JR, Foxcroft GR (1997) Progesterone mediates nutritionally induced effects on embryonic survival in gilts. J.Anim Sci. 75, 1063-1070.

Krzymowski T, Czarnocki J, Koziorowski M, Kotwica J, Stefanczyk-Krzymowska S (1986) Counter Current transfer of 3H-PGF-2alfa in the ,esometrium: A possible mechanism for prevention of luteal regression. Anim. Reprod. Sci. 11, 259-272.

Prime GR, Symonds HW (1993) Influence of plane of nutrition on portal blood flow and the metabolic clearance rate of progesterone in ovariectomized gilts. J. Agric. Sci. 121, 389-397.

Tast A, Halli O, Ahlstrom S, Andersson H, Love RJ, Peltoniemi OAT. Seasonal alterations in circadian melatonin rhythms of the European wild boar and domestic gilt. J Pineal Res 2001; 30(1):43-49.

Virolainen JV., Tast A., Sorsa A., Love RJ., and Peltoniemi OAT. (2003). Changes in feeding level during early pregnancy affect fertility in gilts. Anim. Reprod. Sci., (in press). 